\title{
31. The Vertical Profile of Organic Carbon in the 800 Meter Core Sample from the East Coast of Lake Biwa
}

\author{
By Nobuhiko HANDA and Nobuyuki TANAKA \\ Water Research Institute, Nagoya University, \\ Chikusa-ku, Nagoya 464 \\ (Communicated by Kenjiro Kimura, M. J. A., April 12, 1978)
}

From 1975 to 1976 , a new coring operation was conducted in the east coast of Lake Biwa under the direction of Professor N. Kawai, Osaka University, to study the change in geomagnetic polarity in the past 2.0 million years (my.), especially to find the depth of the sediment showing the boundary age of the Brunhes-Matsuyama Paleomagnetic epoch in the bottom sediment of Lake Biwa. Geochemical studies as well as geological and sedimentalogical works have been undertaken to clarify the paleoclimate of the Lake Biwa area and Japan Islands.

The drilled length of the well was about 945 meters. The top of the first 200 meters of this core sample was discarded during the coring operation, so that a total of 808 meters of the core sample was obtained. This sample was given a geological description by Yokoyama et al. in 1977.

The core sample is very heterogenous in lithofacies and mainly composed of fine to very fine sand layers with some clays, silts, medium to coarse sands, gravels, peats and volcanic ashes. These facts suggest that the aquatic environments for the formation of the sediment at and near the coring site had been very changeable from time to time in the past $1 \mathrm{my}$.

Ten volcanic ash layers have been observed throughout the 800 meter core sample and some of the volcanic ash samples were used for the age determination by use of zircon. The age of the volcanic ash layer of the sample \#125, located at 333.82 meters from the land surface, was determined to be $0.47 \mathrm{my}$. B.P. by the fission track method (Ikebe and Yokoyama, 1977). This layer is assumed to correspond to that (170.19 to $\mathbf{1 7 0 . 5 6}$ meters from the surface of the lake sediment) in the sample \#425 of the 200 meter core sample from Lake Biwa. The volcanic ash layer from 517.80 to 518.57 meters was identified as "azuki ash" which is common in the Osaka and Kobiwako groups and the age of the ash has been determined to be $0.87 \pm 0.07 \mathrm{my}$. B.P. (Ikebe and Yokoyama, 1977). 
In this study, organic carbon, total nitrogen, extractable and fixed ammonium nitrogens, and water content in the sedimentary samples from the long core sample were analyzed to assess the contribution of organic matter of the terrestrial or lacustrine organisms to the sedimentary organic matter. Unexpectedly high concentration of organic carbon was found in the three horizons, in which high concentration of total nitrogen and water content were measured. These data will be discussed in terms of the $\mathrm{C} / \mathrm{N}$ ratio of the sedimentary samples and a wide variety of living organisms.

Organic carbon and total nitrogen in the sedimentary samples were determined by a CHN analyzer. Two hundred $\mathrm{mg}$ of a pulverized dry sediment which has been treated with $0.6 \mathrm{~N} \mathrm{HCl}$ overnight were weighted exactly and transferred to a platinum boat. Organic carbon and total nitrogen were determined by the $\mathrm{CHN}$ analyzer which was maintained at the temperature of $850^{\circ} \mathrm{C}$ in a furnace packed with cupric oxide and at $550^{\circ} \mathrm{C}$ in a furnace packed with cupreous metal.

Organic nitrogen was calculated by subtraction of extractable and fixed ammonium nitrogens from total nitrogen of the sedimentary samples. Exchangeable and fixed ammoniums were determined by the methods described by Bremner and Keeney (1966) and Silva and Bremner (1966), respectively. Exchangeable ammonium was extracted from the sedimentary sample with $\mathrm{KCl}(2 \mathrm{M})$. An aliquot of the extract was transferred to a steam-distillation apparatus which contained boric acid and $\mathrm{MgO}$, and then the ammonium was distilled and determined colorimetrically by use of the Nessler's reagent.

For the determination of fixed ammonium, the sedimentary sample was treated with an alkaline potassium hypobromite ( $\mathrm{KOBr}$ ) solution to remove exchangeable ammonium and organic nitrogen compounds, and the residue was washed with $0.5 \mathrm{M} \mathrm{KCl}$ and shaken with $5 \mathrm{~N} \mathrm{HF}: 1 \mathrm{~N} \mathrm{HCl}$ for $24 \mathrm{hr}$. The ammonium released by the $\mathrm{HF}$ $\mathrm{HCl}$ treatment was separated by steam-distilling the reaction mixture with $\mathrm{KOH}$, and determined colorimetrically by use of the Nessler's reagent. The $\mathrm{KOBr}$ treatment effected almost complete removal of organic nitrogen and exchangeable ammonium from the sedimentary samples. The KOBr-HF method was satisfactory in determining the fixed ammonium because of the simplicity and precision of the analytical procedure.

Water content of the sedimentary samples through the entire length of the core sample was measured in a range from 11.2 to $42 \%$ and the values tended to decrease with depth although it was found that the water content was relatively high at the depth of 289.9 , 377.8 , and $524.5 \mathrm{~m}$.

Extremely high concentration of organic carbon was determined 


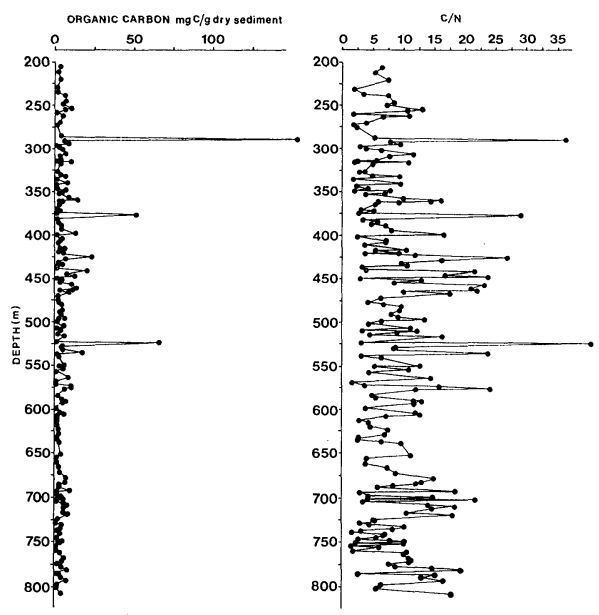

Fig. 1. Vertical profiles of organic carbon and $\mathrm{C} / \mathrm{N}$ ratio in the 800 meter core sample.

in the sedimentary sample at the depth of $289.8,377.8$, and $524.5 \mathrm{~m}$, which consisted of dark brown silt or dark brown sand and looked apparently very rich in organic matter. Except these three sedimentary samples, the concentration of organic carbon was measured in the range from 1 to $10 \mathrm{mgC} / \mathrm{g}$ dry sediment throughout the core sample as shown in Fig. 1. The figures of these values of organic carbon were not much different form those obtained from the 200 meter core sample from Lake Biwa, whose organic matter has been subjected to extensive analytical studies. However, vertical fluctuation of the values of organic carbon was apparent in the 800 meter core sample. This fact also clearly indicates that the figure of the input of organic matter was very changeable when the lake sediments were formed.

The concentration of total nitrogen tended to decrease with depth from 0.75 to $0.25 \mathrm{mgN} / \mathrm{g}$ dry sediment, while high concentration of total nitrogen was found at the depth of $289.8,377.8$, and $524.5 \mathrm{~m}$. These depths correspond to high concentration of total organic carbon.

The weight ratio of organic carbon to total nitrogen $(\mathrm{C} / \mathrm{N}$ ratio) is frequently used to characterize organic matter in microorganisms, plants, animals and geological samples. $\mathrm{C} / \mathrm{N}$ ratios of the organic matter in the 800 meter core sample were calculated. The values of the $\mathrm{C} / \mathrm{N}$ ratio were obtained in the range from 1.5 to 40.3 through the entire length of the core sample, while no systematic change in the $\mathrm{C} / \mathrm{N}$ ratio was observed vertically. Since proteins, the main nitrogen compounds of living organisms, have the $\mathrm{C} / \mathrm{N}$ ratio of about 3 , animal organisms, which are rich in protein are low in the $\mathrm{C} / \mathrm{N}$ ratio, e.g., polychaetes, 3.4; fish and fish larvae, 3.9 ; and copepods, 4.3 (Beers, 
1966). Thus, it is assumed that the $\mathrm{C} / \mathrm{N}$ ratio is as low as less than 3 in the present core sample because of the fixation of ammonium derived from the degradation process of organic matter during burial and of the interlayers of alumina silicates possessing high layer charges. But it is unlikely that it is due to the presence of a certain organic matter rich in nitrogen. It has been generally accepted that sediments and soils contain large amounts of fixed ammonium relative to the organic matter and thus the ratios of organic carbon to total nitrogen do not reflect the true chemical composition of the sedimentary or soil organic matter unless corrected for the inorganic nitrogen fraction (Bremner, 1959 ; Mogilevkina, 1964 ; Page et al., 1967 ; Stevenson and Tils, 1966).

A preliminary examination was conducted for the analysis of extractable and fixed ammonium nitrogen by use of some sedimentary samples which proved to be widely different in the $\mathrm{C} / \mathrm{N}$ ratio among themselves. It was determined that the $\mathrm{C} / \mathrm{N}$ ratio of the sample \#41 was far less than 3 while it was measured that these of the samples \#39 and \#43 were about 10, a value which is virtually identical with the value obtained in a wide variety of soil samples (Kononova, 1966). Substantial amounts of extractable and fixed ammonium nitrogen were determined in the sample \#41 as well as in the samples \#39 and \#43 as shown in Table I. Extractable and fixed ammonium nitrogens were measured at 48 and $43 \%$ of total nitrogen respectively in the sample \#41, while these ammonium nitrogens were found to have a little lower values in the samples \#39 and \#43.

Subtracting total ammonium nitrogen from total nitrogen, 0.38,

Table I. Organic carbon, total and organic nitrogens, extractable and fixed ammonium nitrogens and $\mathrm{C} / \mathrm{N}$ ratios of the sediments from 800 meter core sample from the east coast of Lake Biwa

\begin{tabular}{lccc}
\hline \multicolumn{1}{c}{ Sample \# } & 39 & 41 & 43 \\
\hline Depth (m) & 256.2 & 259.8 & 261.5 \\
Water content (\%) & 26.0 & 24.9 & 22.4 \\
Organic carbon mC/g dry sediment & 6.54 & 1.36 & 5.44 \\
Total Nitrogen mgN/g dry sediment & 0.63 & 0.83 & 0.50 \\
C/N & 10.4 & 1.64 & 10.9 \\
$\begin{array}{l}\text { Extractable ammonium nitrogen (E-N) } \\
\text { mgN/g dry sediment }\end{array}$ & 0.08 & 0.14 & 0.04 \\
$\begin{array}{l}\text { Fixed ammonium nitrogen (F-N) } \\
\text { mgN/g dry sediment }\end{array}$ & 0.17 & 0.33 & 0.14 \\
$\begin{array}{l}\text { Total ammonium nitrogen } \\
\text { mgN/g dry sediment }\end{array}$ & 0.25 & 0.47 & 0.18 \\
$\begin{array}{l}\text { Organic nitrogen } \\
\text { (total nitrogen-total ammonium nitrogen) }\end{array}$ & 0.38 & 0.36 & 0.32 \\
$\quad$ mgN/g dry sediment \\
C/N org.
\end{tabular}


0.36 and $0.32 \mathrm{mgN} / \mathrm{g}$ dry sediment were obtained as organic nitrogen and thus it is calculated that the ratio of organic carbon to organic nitrogen is $17.2,3.77$ and 17.0 in the sedimentary samples \#39, \#41 and \#43, respectively. These data clearly indicate that sources of organic matter must be different among the sedimentary samples \#39, \#41 and \#43.

Lower plants are relatively rich in protein and are low in the $\mathrm{C} / \mathrm{N}$ ratio, e.g., blue-green algae, 6.5 (Vinogradov, 1953) ; peridineans, 4.6-7.3; and diatoms, 5.5-7.5 (Bordowskiy, 1965; Vaccaro, 1965). Apart from these algae, higher plants which are the main contributor to organic matter in terrestrial and near shore environments contain less than $20 \%$ protein and therefore show a high $\mathrm{C} / \mathrm{N}$ ratio, e.g., corn plant, 30.4 (Marlett and Edman, 1959) ; Zostera, 14-21 (Bordowskiy, 1965) ; and Leguminosae, 15-25 (Scheffer and Schachtschabel, 1970). Soils have also high $\mathrm{C} / \mathrm{N}$ ratios than animals and lower plants because of the terrestrial source of organic matter.

These facts obviously suggest that organic matter of the sedimentary samples showing low $\mathrm{C} / \mathrm{N}$ ratios such as the sample \#41 is mostly derived from autochthonous animals and lower plants, probably a wide variety of algae, while the preferential input of terrestrial higher plants and soils to the bottom sediment of the lake occurred in the sedimentary samples showing high $\mathrm{C} / \mathrm{N}$ ratios as observed in the samples \#39, and \#43. Relatively low values of the ratio of organic carbon to organic nitrogen and found, ranging 3 to 11 in the sedimentary samples which are low in the $\mathrm{C} / \mathrm{N}$ ratio, and these data will be published elsewhere. Thus, it can be concluded that the ratio of organic carbon to organic nitrogen in the sedimentary samples is a very useful diagnostic tool to assess the contributions of autochthonous and allchthonous materials to the sedimentary organic matter.

\section{References}

Beer, J. B. (1966) : Studies on the chemical composition of the major zooplankton groups in the Sargasso Sea off Bermuda. Limnol. Oceanogr., 11, 520-528.

Bordowskiy, O. K. (1965) : Sources of organic matter in bottom sediments. Mar. Geol., 3, 5-31.

Bremner, J. M. (1959) : Determination of fixed ammonium in soil. J. Agr. Sci., 52, 147-160.

Bremner, J. M., and D. R. Keeney (1966) : Determination and isotope-ratio analysis of different forms of nitrogen in soil.: 3. Exchangeable ammonium, nitrate, and nitrite by extraction-distillation methods. Soil Sci. Soc. Amer. Proc., 30, $577-582$.

Ikebe, N., and T. Yokoyama (1977) : General explanation of the Kobiwako group -Ancient lake deposits of Lake Biwa. Paleolimnology of Lake Biwa and the Japanese Pleistocene, 4, 31-51. 
Kononova, M. M. (1966) : Soil Organic Matter. 2nd ed., New York, Pergamon Press, Inc.

Marlett, E. M., and J. G. Edman (1959): Carbon-nitrogen distribution and nitrogen type relationships in recent and ancient sediments. Div. of Petroleum chemistry, Am. Chem. Soc., 135th Meeting, pp.107-119.

Mogilevkina, I. A. (1964) : Fixation of ammonium in soil and method of determining it. Soviet Soil Sci., 2, 185-196.

Page, A. L., W. D. Burge, T. J. Ganje, and M. J. Garber (1967) : Potassium and ammonium fixation by vermiculitic soils. Soil Sci. Soc. Am. Proc., 31, 337-341.

Scheffer, F., and P. Schachtschabel (1970) : Lehrbuch der Boden-Kunde. 7th Edn., Enke.

Siloa, J. A., and J. M. Bremner (1966) : Determination and isotoperatio analysis of different forms of nitrogen in soils: 5. Fixed ammonium. Soil Sci. Soc. Amer. Proc., 30, 587-594.

Steeven, F. J., and S. N. Tils (1966) : Nitrogenous constituents in deep-sea sediments. Advances in Organic Geochemistry (G. D. Hobson, and G. C. Speers eds.), pp. 227-253, Pergamon Press.

Vaccaro, R. F. (1965): Biogeochemistry of organic matter. II. Thermal reaction kinetics and transformation products of amino compounds. Geochim. Cosmochim. Acta, 28, 157-188.

Vinogradov, A. P. (1953): The elementary chemical composition of marine organisms. Mem. Sears Found. Mar. Res., II. 